\title{
Silvopastoral Systems Enhance Soil Quality in Grasslands of Colombia
}

\author{
Judith Martínez, ${ }^{1,2}$ Yasmín S. Cajas, ${ }^{1}$ Juan D. León, ${ }^{2}$ and Nelson W. Osorio ${ }^{2}$ \\ ${ }^{1}$ CORPOICA Turipaná, Km. 13 vía Montería-Cereté, Córdoba, Colombia \\ ${ }^{2}$ Universidad Nacional de Colombia, Calle 59 No. 63-20, 050034 Medellín, Colombia
}

Correspondence should be addressed to Juan D. León; jdleon@unal.edu.co

Received 31 July 2013; Revised 16 November 2013; Accepted 1 December 2013; Published 22 January 2014

Academic Editor: Robert L. Bradley

Copyright (C) 2014 Judith Martínez et al. This is an open access article distributed under the Creative Commons Attribution License, which permits unrestricted use, distribution, and reproduction in any medium, provided the original work is properly cited.

In the tropical drylands of Colombia, the soils subjected to traditional systems of livestock production are severely degraded and depleted of plant nutrients. Multistrata silvopastoral systems are viable alternatives to improve livestock production; however, it is unknown whether these systems can reduce the negative environmental impacts of traditional systems on soil quality. The objective of this study was to evaluate the effects of 13-year-old multistrata silvopastoral systems on soil quality parameters in degraded soils of the Sinu River Valley, Colombia. The results show that the trees in the silvopastoral systems increased or maintained soil $\mathrm{pH}$ values and nutrient availability (phosphorus, potassium, and calcium) with respect to the pastures with only grasses. The effects were significantly controlled by the types of plant species, particularly Guazuma ulmifolia and Cassia grandis.

\section{Introduction}

Soil degradation is one of the major constraints in the tropics affecting 500 million ha [1], threatening ecosystem services and food security for people in developing countries [2]. The Caribbean region of Colombia is an unfortunately example of this situation because $80-100 \%$ of the grasslands exhibit soil erosion, soil compaction, and low soil nutrient availability for livestock systems [3-6]. The major cause is overgrazing and lack of proper management practices such as monoculture of Gramineae versus plant diversity, adequate fertilization, soil conservation practices, and reduced tillage [7-10]. Consequently, over time, these soils exhibit high level of compaction (2.2-4.2 MPa) and low levels of plant nutrients (e.g., phosphate: $<10 \mathrm{mg} \mathrm{kg}^{-1}$ and potassium: $<0.11 \mathrm{cmol}_{\mathrm{c}} \mathrm{kg}^{-1}$ ) that diminishes forage quality and availability, particularly in the long dry season $[4,6]$. As a result of that, there is low animal carrying capacity (one animal per ha), low weight gain $\left(<300 \mathrm{~g} \mathrm{day}^{-1}\right)$, late age for slaughter (30-36 months), and high cost of production (US\$ $0.80 \mathrm{~kg}^{-1}$ ) $[6,8]$.

As an alternatives, silvopastoral systems can be successfully implemented because they can provide several benefits: animal comfort and productivity, litter supply, nutrient cycling, water infiltration, soil bulk density, soil fauna, and biodiversity [11-16]. Unfortunately, in the tropics, there are not sufficient data to support these claims on soil quality parameters [17-19] as it occurs in the temperate zone [20-22], which limits the widespread use of this strategy [23-25].

Our hypothesis in this study was that soil quality parameters (e.g., soil $\mathrm{pH}$, soil organic matter, and plant nutrient availability) may be enhanced by silvopastoral arrangements in comparison with a pasture of Gramineae monoculture; however, the magnitude of this effect may depend on the tree species considered in the arrangement. Thus, the aim was to evaluate the effect of 13-year-old multistrata silvopastoral arrangements on soil quality parameters.

\section{Materials and Methods}

2.1. Site. This study was conducted in the experimental station of CORPOICA-Turipaná at Cereté, Córdoba, Colombia $\left(8^{\circ} 51^{\prime} \mathrm{N}, 75^{\circ} 49^{\prime} \mathrm{W}\right.$, altitude $18 \mathrm{~m}$ a.s.l.). This region has two contrasting seasons: a rainy period from May to November and a dry period from December to April. The annual precipitation is $1380 \mathrm{~mm}$, the mean temperature is $28^{\circ} \mathrm{C}$, the air humidity is $81 \%$, and potential evapotranspiration is $1240 \mathrm{~mm}$ 
TABLE 1: Multistrata silvopastoral systems evaluated in the Sinu River Valley, Colombia.

\begin{tabular}{|c|c|c|c|c|c|c|}
\hline System & Composition & Plant species & Distance $(\mathrm{m})^{*}$ & No. of trees per ha & Tree height $(\mathrm{m})$ & $\mathrm{DBH}(\mathrm{cm})^{* *}$ \\
\hline \multirow{2}{*}{ A0 } & \multirow{2}{*}{ Pasture } & D. aristatum & - & - & - & - \\
\hline & & P. maximum & - & - & - & - \\
\hline \multirow{5}{*}{$\mathrm{A} 1$} & \multirow{5}{*}{ Pasture and trees } & D. aristatum & - & - & - & - \\
\hline & & P. maximum & - & - & - & - \\
\hline & & G. ulmifolia & & 11 & $12.2 \pm 1.1$ & $42.4 \pm 6.7$ \\
\hline & & C. grandis & $16 \times 16$ & 11 & $13.3 \pm 0.5$ & $36.3 \pm 2.2$ \\
\hline & & A. saman & & $11 / 33$ & $19.2+2.0$ & $68.0 \pm 2.9$ \\
\hline \multirow{7}{*}{ A2 } & \multirow{7}{*}{ Pasture, trees, and shrubs } & D. aristatum & - & - & - & - \\
\hline & & P. maximum & - & - & - & - \\
\hline & & G. ulmifolia & \multirow{3}{*}{$16 \times 16$ for trees } & 11 & $12.8 \pm 1.1$ & $54.7 \pm 6.7$ \\
\hline & & C. grandis & & 11 & $14.0 \pm 0.5$ & $38.6 \pm 2.2$ \\
\hline & & A. saman & & 11 & $21.4 \pm 2.0$ & $67.3 \pm 2.9$ \\
\hline & & C. cujete & \multirow{2}{*}{$4 \times 4$ for shrubs } & 300 & - & - \\
\hline & & L. leucocephala & & $300 / 633$ & - & - \\
\hline \multirow{9}{*}{ A3 } & \multirow{9}{*}{ Pasture, trees, shrubs, and timber trees } & D. aristatum & - & - & - & - \\
\hline & & P. maximum & - & - & - & - \\
\hline & & G. ulmifolia & \multirow{3}{*}{$16 \times 16$ for trees } & 11 & $13.2 \pm 1.1$ & $43.3 \pm 6.7$ \\
\hline & & C. grandis & & 11 & $12.1 \pm 0.5$ & $40.3 \pm 2.2$ \\
\hline & & A. saman & & 11 & $21.2 \pm 2.0$ & $66.9 \pm 2.9$ \\
\hline & & C. cujete & \multirow{2}{*}{$4 \times 4$ for shrubs } & 300 & - & - \\
\hline & & L. leucocephala & & 300 & - & - \\
\hline & & P. quinata & \multirow{2}{*}{$16 \times 16$ for timber trees } & 11 & $19.2 \pm 1.1$ & $58.6 \pm 2.2$ \\
\hline & & S. macrophylla & & $11 / 655$ & $12.3 \pm 1.5$ & $27.3 \pm 1.9$ \\
\hline
\end{tabular}

${ }^{*}$ At planting, the initial distance among trees was $8 \times 8 \mathrm{~m}$; four years later, the trees were thinned to $16 \times 16 \mathrm{~m}$.

** DBH: diameter at breast height \pm standard deviation.

per year. According to Holdridge [26], the ecological life-zone is tropical dry forest.

2.2. Silvopastoral Systems. For this study, we used the plots established by Cajas-Giron and Sinclair [8] in 1998 (Table 1). The selection of plant species in the multistrata systems was designed according to the relative frequency in the region, the potential utility for livestock feed, and the acceptance of farmers, a critical factor to adopt these systems [27, 28]. The experimental design was a completely randomized block design (blocking according to the natural soil drainage); in each block, there were three different silvopastoral arrangements and a control pasture composed of only grasses (Dichanthium aristatum and Panicum maximum; A0) that represents the traditional livestock production system in the region; the other systems besides grasses included three types of trees (Guazuma ulmifolia, Cassia grandis, and Albizia saman; A1), trees and two shrubs (G. ulmifolia, C. grandis, A. saman, Crescentia cujete, and Leucaena leucocephala; A2), and trees, shrubs, and two timber trees (G. ulmifolia, C. grandis, A. saman, C. cujete, L. leucocephala, Pachira quinata, and Swietenia macrophylla; A3) (Table 1). The livestock feed directly on grasses and shrubs (C. cujete and L. leucocephala). Each experimental plot had a size of $100 \times 200 \mathrm{~m}(2 \mathrm{ha})$ and three replicates (total of 12 plots, 24 ha).

2.3. Soil Sampling and Testing. In June 2010, surface $(0-5 \mathrm{~cm})$ soil samples associated with each plant species were collected in the experimental plots. For this purpose, in each plot, we selected at random 10 trees of each plant species, and four subsamples of the soil around their root system were collected. These 40 subsamples were thoroughly mixed to form a single soil sample per plant species per plot. In this way, 1560 soil subsamples were collected in the plots, which represented 39 soil samples (Table 2 ).

The soil samples were analyzed in the Soil and Plant Testing Laboratory of CORPOICA-Tibaitata at Mosquera, Colombia. Soil test was soil $\mathrm{pH}$ (water, $1: 2.5$ ), phosphorus (Bray-II), calcium, potassium, and magnesium (1 M ammonium acetate); soil organic matter content (Walkley-Black), organic carbon in humic substances, and the $E_{4} / E_{6}$ ratio were measured in a spectrophotometer at 465 and $665 \mathrm{~nm}$ in the $\mathrm{NaHCO}_{3}$ extract [29]. Details about soil analysis methods are available in Westerman [30].

2.4. Statistical Analysis. Data were subjected to analysis of variance and mean separation by Tukey's test with $P$ value of 0.05 . Statistical analyses were carried out with the software SAS version 9.2 (SAS Systems inc., NC, USA).

\section{Results}

3.1. Soil $p H$. The soil $\mathrm{pH}$ values associated with $D$. aristatum ( $\mathrm{pH} 5.5$ ) and $P$. maximum ( $\mathrm{pH}$ 5.9) were significantly $(P<0.05)$ lower than the soil $\mathrm{pH}$ found associated with 
TABLE 2: Number of soil subsamples collected and composite samples associated with plant species in silvopastoral systems in the Sinu River Valley, Colombia.

\begin{tabular}{|c|c|c|c|c|c|}
\hline System & Composition & Plant species & $\begin{array}{c}\text { No. of subsamples } \\
\text { per plant species in } \\
\text { each plot }\end{array}$ & $\begin{array}{c}\text { No. of subsamples } \\
\text { per plant species in } \\
\text { each system }\end{array}$ & $\begin{array}{l}\text { No. of composite } \\
\text { samples per system }\end{array}$ \\
\hline \multirow{2}{*}{ A0 } & \multirow{2}{*}{ Pasture } & D. aristatum & 40 & \multirow{2}{*}{240} & \multirow[t]{2}{*}{6} \\
\hline & & P. maximum & 40 & & \\
\hline \multirow{3}{*}{$\mathrm{A} 1$} & \multirow{3}{*}{$\begin{array}{l}\text { Pasture and } \\
\text { trees }\end{array}$} & G. ulmifolia & 40 & \multirow{3}{*}{360} & \multirow{3}{*}{9} \\
\hline & & C. grandis & 40 & & \\
\hline & & A. saman & 40 & & \\
\hline \multirow{3}{*}{$\mathrm{A} 2$} & \multirow{3}{*}{$\begin{array}{l}\text { Pasture, trees, } \\
\text { and shrubs }\end{array}$} & G. ulmifolia & 40 & \multirow{3}{*}{360} & \multirow{3}{*}{9} \\
\hline & & C. grandis & 40 & & \\
\hline & & A. saman & 40 & & \\
\hline \multirow{5}{*}{ A3 } & \multirow{5}{*}{$\begin{array}{l}\text { Pasture, trees, } \\
\text { shrubs, and } \\
\text { timber trees }\end{array}$} & G. ulmifolia & 40 & \multirow{5}{*}{600} & \multirow{5}{*}{15} \\
\hline & & C. grandis & 40 & & \\
\hline & & A. saman & 40 & & \\
\hline & & P. quinata & 40 & & \\
\hline & & S. macrophylla & 40 & & \\
\hline Total & & & 520 & 1560 & 39 \\
\hline
\end{tabular}

G. ulmifolia in the A2 and A3 systems ( $\mathrm{pH} 6.4,6.2)$ and $C$. grandis in the A3 system (pH 6.2) (Figure 1(a)).

3.2. Soil Phosphate. Consistently, the soil associated to the grasses had very low levels of available $\mathrm{P}\left(<10 \mathrm{mg} \mathrm{kg}^{-1}\right)$, which were significantly $(P<0.05)$ lower than those of the soil associated to the trees. The highest soil $P$ levels were detected with G. ulmifolia in the systems A2 and A3 (24-28 $\mathrm{mg} \mathrm{kg}^{-1}$ ) and C. grandis in the systems A1 and A2 (24-27 $\left.\mathrm{mg} \mathrm{kg}^{-1}\right)$ (Figure 1(b)).

3.3. Soil Exchangeable Bases. The level of soil exchangeable $\mathrm{K}^{+}$in the pasture $\left(\sim 0.8 \mathrm{cmol}_{\mathrm{c}} \mathrm{kg}^{-1}\right)$ was significantly lower than that associated with the trees, particularly with $G$. ulmifolia and C. grandis in the system A2 (1.3-1.4 $\left.\mathrm{cmol}_{\mathrm{c}} \mathrm{kg}^{-1}\right)$ (Figure 1(c)). These differences represented $63-75 \%$ more exchangeable $\mathrm{K}^{+}$in the soil associated with these tree species than in the soils of the grasses.

The levels of exchangeable $\mathrm{Ca}^{2+}$ had a similar behavior to that of exchangeable $\mathrm{K}^{+}$. Thus, the soil $\mathrm{Ca}^{2+}$ levels associated with the grasses $D$. aristatum and $P$. maximum (10.7 and $10.8 \mathrm{cmol}_{\mathrm{c}} \mathrm{kg}^{-1}$ ) were significantly lower than those found in the soil associated with G. ulmifolia and C. grandis in systems A2 and A3 (13.8-14.6 $\mathrm{cmol}_{\mathrm{c}} \mathrm{kg}^{-1}$ ) (Figure 1(d)). These differences represented $29-36 \%$ more exchangeable $\mathrm{Ca}^{2+}$ in the soil associated with these tree species than in the soil of the grasses.

In contrast, there were not significant differences in the levels of exchangeable $\mathrm{Mg}^{2+}$ in the soil associated with the grasses and the tree species (Figure 1(e)). It is noteworthy that all soil samples collected had very high values of exchangeable $\mathrm{Mg}^{2+}\left(6.6-10.4 \mathrm{cmol}_{\mathrm{c}} \mathrm{kg}^{-1}\right)$.
3.4. Soil Organic Matter Content. There were significant differences $(P \leq 0.05)$ in the soil organic matter content among soils associated with $C$. grandis in systems A2 and A3 (10.9\%) and those associated with $P$. quinata in system A3 (7.6\%) and A. saman in systems A1 and A3 (8.6-8.4\%). The soil organic matter content in the pastures $D$. aristatum and P. maximum (8.9 and 9.3\%) did not exhibit significant differences with those soils associated with the tree species (Figure 2(a)).

3.5. Humic Substances. There were not significant differences in the carbon content of humic substances and humic acids in the soil associated with tree species and grasses. The values fluctuated between $45.3-56.1 \%$ and $22.0-31.4 \%$, respectively (Figures $2(\mathrm{~b})$ and $2(\mathrm{c})$ ). The $E_{4} / E_{6}$ ratio in the humic substances ranged between 10.8 and 11.9; however, these values did not exhibit significant differences among soil samples associated with grasses and tree species (Figure 2(d)).

\section{Discussion}

The results of this study demonstrate that some soil quality parameters (soil $\mathrm{pH}, \mathrm{P}, \mathrm{K}, \mathrm{Ca}$, and organic matter) were enhanced by the presence of tree species in silvopastoral systems. Similar results have been reported by Mafongoya et al. in South Africa [31], Fernandes et al. [32] in the Amazon basin, and Lemenih et al. [16] in Ethiopia. In this way, the soil $\mathrm{pH}$ and availability levels of $\mathrm{P}, \mathrm{K}$, and $\mathrm{Ca}$ associated with some tree species were significantly higher in comparison to those levels in the soil of a pasture with D. aristatum and $P$. maximum. The effects found were associated with the tree species involved rather than the silvopastoral arrangement. It is noteworthy that the soil associated with G. ulmifolia in system A2 had around three times more $\mathrm{P}\left(28 \mathrm{mg} \mathrm{kg}^{-1}\right)$ 


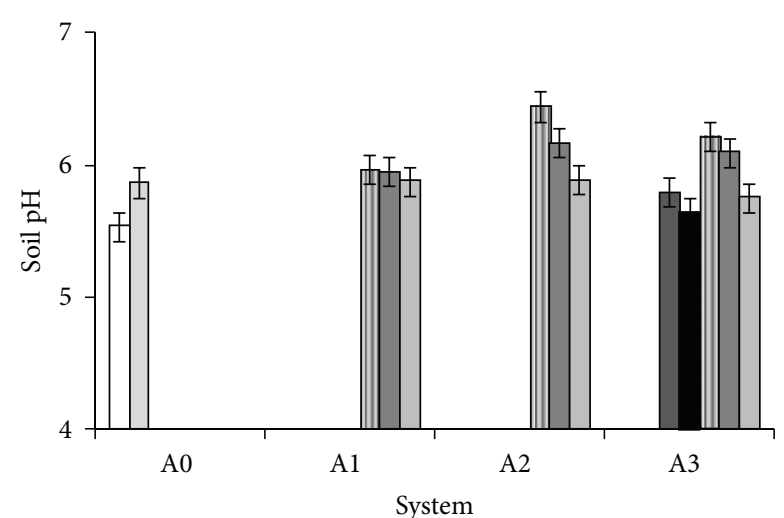

(a)

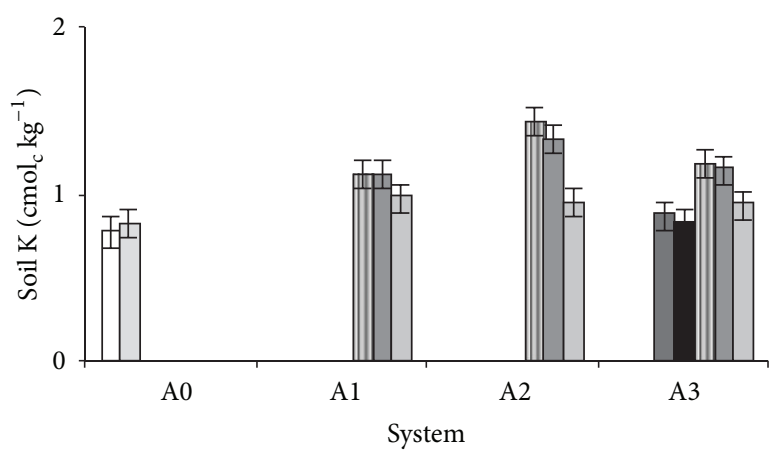

(c)

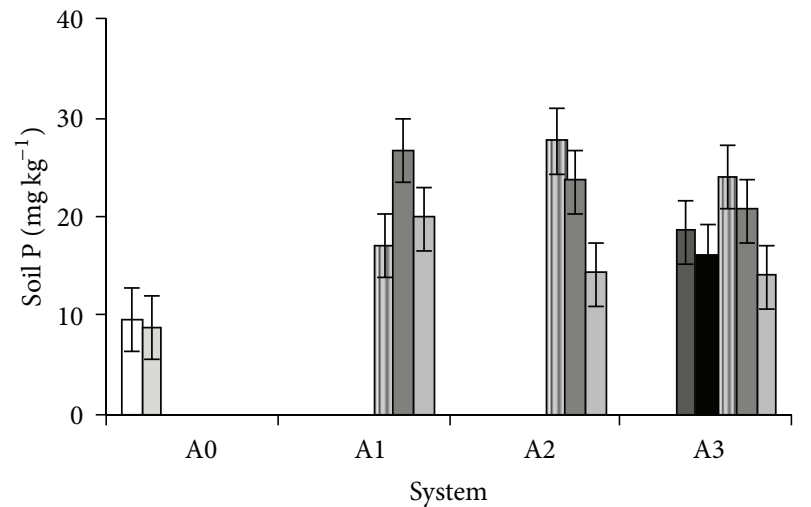

(b)

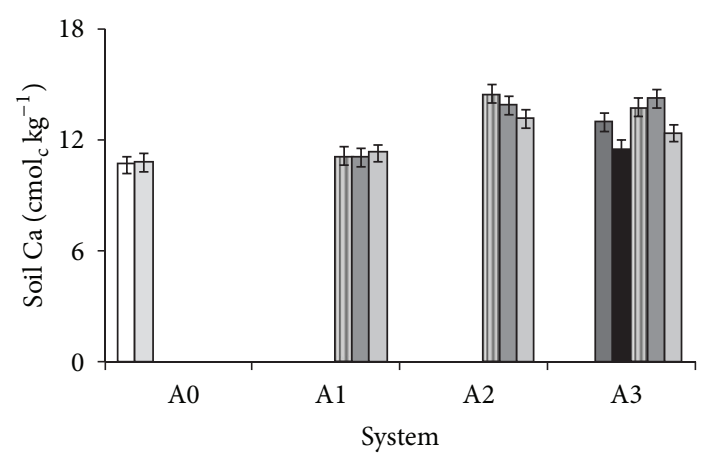

(d)

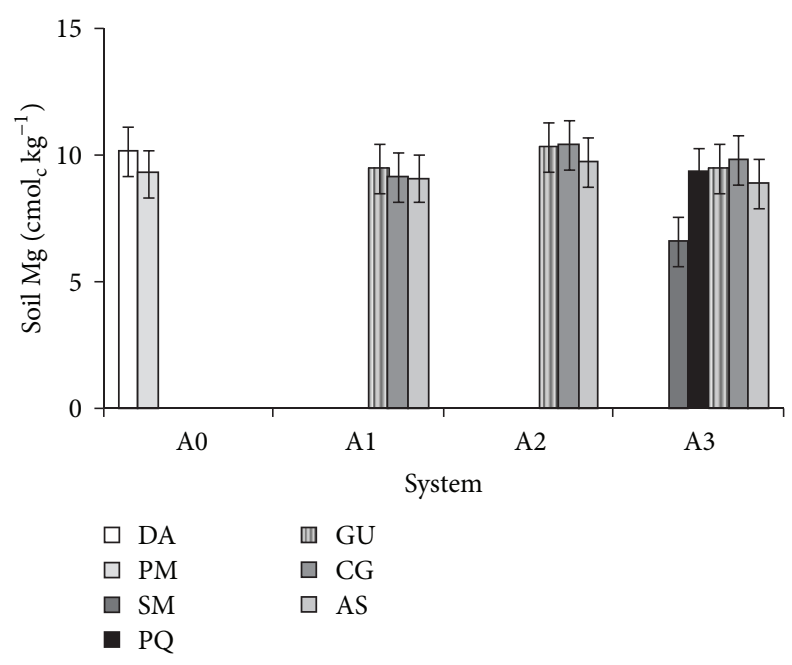

(e)

FIGURE 1: Soil fertility parameters associated with pastures and tree species in multistrata silvopastoral systems in the Sinu Valley, Colombia. Abbreviations: D. aristatum (DA); P. maximum (PM); G. ulmifolia (GU); C. grandis (CG); A. saman (AS); P. quinata (PQ); S. macrophylla (SM).

than the soil in the pastures (P. maximum: $9 \mathrm{mg} \mathrm{kg}^{-1}$ and $D$. aristatum: $\left.10 \mathrm{mg} \mathrm{kg}^{-1}\right)$. Also, the soil $\mathrm{P}$ associated with other tree species was on average twice that of the pastures. These results are consistent with high levels of litter production in the silvopastoral system as shown by some authors [33-37]. It is worth mentioning that $G$. ulmifolia was the tree species with higher annual P returns to the soil via leaf litter production
$[4,6,8]$, which can explain the higher level of soil bioavailable $\mathrm{P}$ in the soil associated with this species.

These results contrast the reports of Montagnini [38] in 5-year-old plantations of Jacaranda copaia and Vochysia guatemalensis where soil available $\mathrm{P}, \mathrm{K}$, and Ca were diminished. However, there were increases in soil available $\mathrm{Ca}$ under the trees Terminalia amazonia $\left(0.5 \mathrm{cmol}_{c} \mathrm{~L}^{-1}\right)$ and 


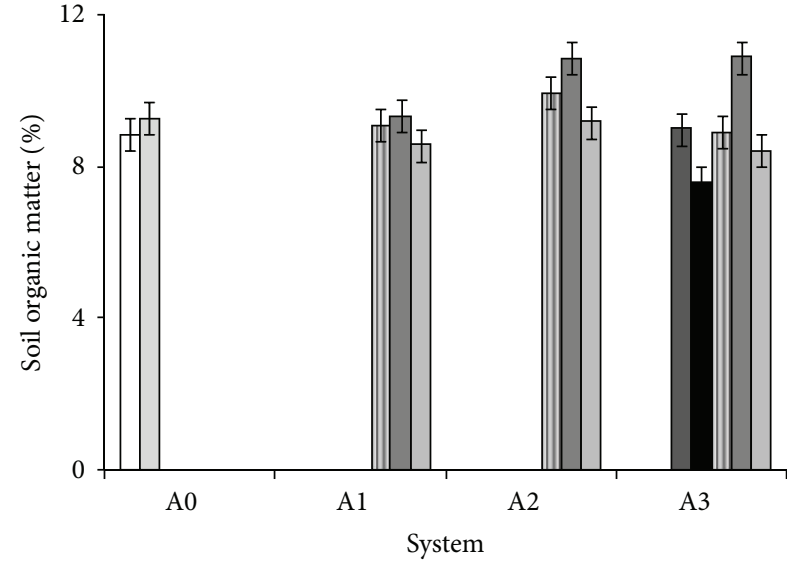

(a)

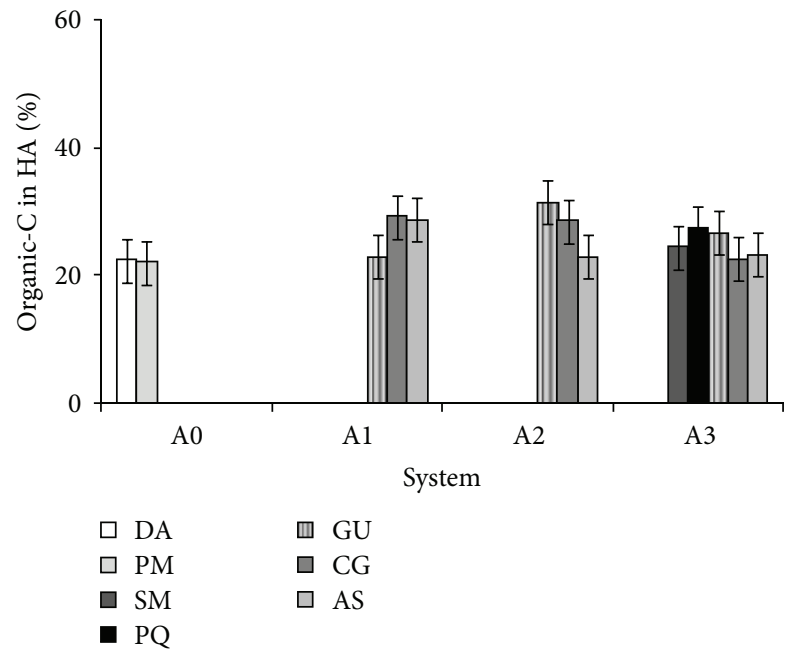

(c)

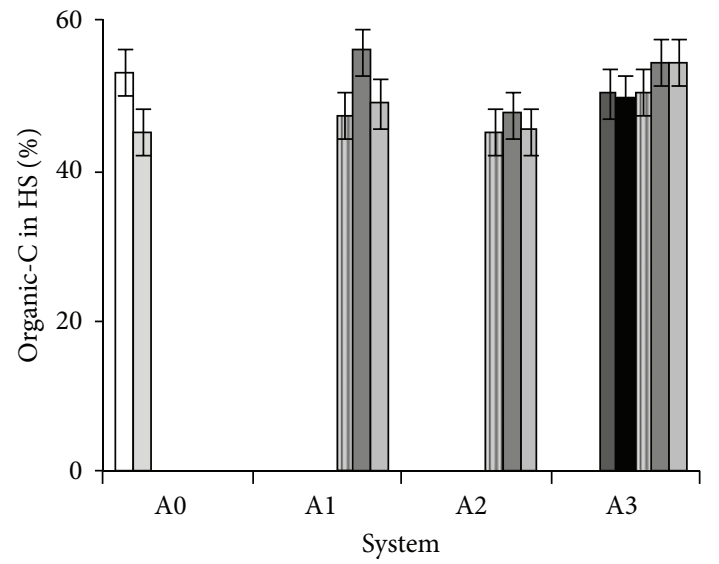

(b)

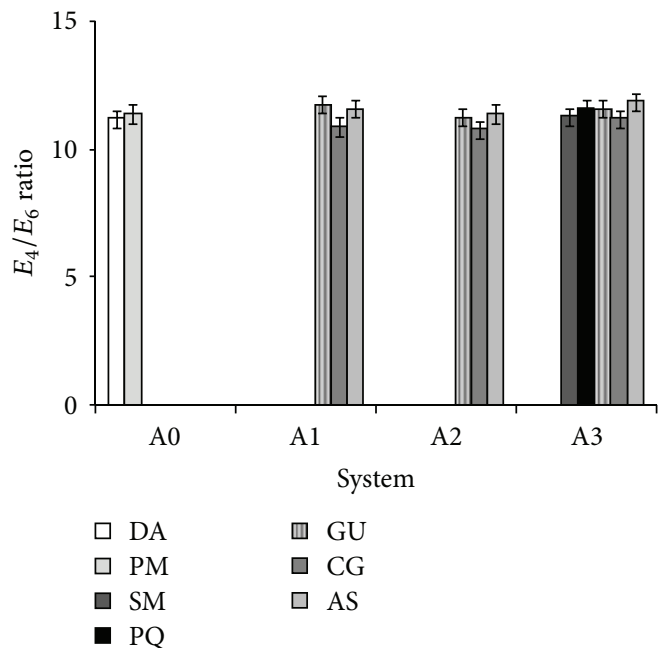

(d)

Figure 2: Soil organic matter content, carbon in humic substances, and $E_{4} / E_{6}$ ratio of soils associated with pastures and tree species in multistrata silvopastoral systems in the Sinu Valley, Colombia. Abbreviations: D. aristatum (DA); P. maximum (PM); G. ulmifolia (GU); C. grandis (CG); A. saman (AS); P. quinata (PQ); S. macrophylla (SM); carbon (C); humic substances (HS); humic acids (HA).

Virola koschnyi $\left(0.45 \mathrm{cmol}_{\mathrm{c}} \mathrm{L}^{-1}\right)$. Both species exhibited high levels of $\mathrm{Ca}$ in the leaves and high rates of litter production. Kershnar and Montagnini [39] reported that, in a soil planted with Hyeronima alchorneoides, higher levels of soil available $\mathrm{Ca}\left(0.65 \mathrm{cmol}_{\mathrm{c}} \mathrm{L}^{-1}\right), \mathrm{Mg}\left(0.45 \mathrm{cmol}_{\mathrm{c}} \mathrm{L}^{-1}\right)$, and organic matter $(0-5 \mathrm{~cm}: 12.7 \%, 5-15 \mathrm{~cm}: 6.2 \%)$ were detected than in plantations of Vochysia ferruginea (Ca: $0.5 \mathrm{cmol}_{\mathrm{c}} \mathrm{L}^{-1}, \mathrm{Mg}: 0.25 \mathrm{cmol}_{\mathrm{c}} \mathrm{L}^{-1}$, organic matter: $0-5 \mathrm{~cm}$ : $12.2 \%, 5-15 \mathrm{~cm}: 6.0 \%$ ), Balizia elegans (Ca: $0.45 \mathrm{cmol}_{\mathrm{c}} \mathrm{L}^{-1}$, Mg: $0.30 \mathrm{cmol}_{c} \mathrm{~L}^{-1}$, organic matter: $0-5 \mathrm{~cm}: 9.0 \%, 5-15 \mathrm{~cm}$ : $6.0 \%$ ), and Genipa americana (Ca: $0.60 \mathrm{cmol}_{\mathrm{c}} \mathrm{L}^{-1}, \mathrm{Mg}$ : $0.40 \mathrm{cmol}_{c} \mathrm{~L}^{-1}$, organic matter: $0-5 \mathrm{~cm}: 9.0,5-15 \mathrm{~cm}: 6.0 \%$ ).

On the other hand, in studies conducted by Velasco et al. [40] in silvopastoral systems with the grass Brachiaria humidicola and Acacia mangium (at two densities: 120 and 240 trees $\mathrm{ha}^{-1}$ ), the soil available $\mathrm{P}$ increased in the soil associated with $A$. mangium at the highest tree density (232 $\left.\mathrm{mg} \mathrm{L}^{-1}\right)$ relative to the lowest tree density $\left(80 \mathrm{mg} \mathrm{L}^{-1}\right)$ with respect to the soil under monoculture of $B$. humidicola $\left(3 \mathrm{mg} \mathrm{L}^{-1}\right)$. It is evident that the tree density and the amount and quality of litter control the nutrient return into the soil and consequently the soil nutrient availability. A. mangium has been also used in land restoration given its capability to reactivate biogeochemical nutrient cycles in degraded soils via litter fall and decomposition [41, 42]. While, in the silvopastoral systems of the current study, the P return through the litter was $1-3 \mathrm{~kg} \mathrm{ha}^{-1} \mathrm{yr}^{-1}$, in the pasture this was only $0.2-0.8 \mathrm{~kg} \mathrm{ha}^{-1} \mathrm{yr}^{-1}$. We did not consider the nutrient return via animal excreta, which can constitute a significant P supply into the soil [43].

The low levels of soil available $P$ found in the pastures of soils from the Sinu River Valley are surprising because these soils have been characterized with high soil fertility parameters, particularly P. However, these soils have been subjected for many decades, since the 1840s [44], to a constant nutrient removal (for meat and milk production) without soil 
nutrient restitution with fertilizers. Over time, the soils have become depleted in some nutrients given their low soil $\mathrm{P}$ buffer capacity [45].

Parrotta [46] found that, when the silvopastoral species Casuarina equisetifolia, Eucalyptus robusta, and L. leucocephala were grown concomitantly (C. equisetifolia/E. robusta, C. equisetifolia/L. leucocephala, and L. leucocephalal E. robusta), the soil had higher total $\mathrm{N}$, concentrations of nutrients (K, $\mathrm{Mg}, \mathrm{Na}$, and $\mathrm{Fe}$ ), and soil organic matter than when the species were grown in monoculture.

In the current study the soil organic matter content was higher with C. grandis and G. ulmifolia. Both tree species exhibited contrasting litter decomposition rates $(k)$ [6], thus suggesting that the amount of litter production and their decay rates are controlling the soil nutrient availability. Similar results have been reported by Mafongoya et al. [31], Castellanos-Barliza and Leon [42], and Celentano et al. [47].

On the other hand, it is not surprising that, in the current study, there were not significant differences in the organic$C$ content of humic substances and humic acids and in the $E_{4} / E_{6}$ ratio in the soil associated with the different plant species considered (including the grasses). Under the soil and weather conditions studied (tropical dry forest), dominance of mineralization over humification is expected. This was quite evident from other studies where we measured the rate of litter decomposition of several plant species (trees and grasses) with the litter-bag technique $[6,10]$. Most of the litter materials were completely decomposed in one year or less. The values of the $E_{4} / E_{6}$ ratios ( 11.0$)$ indicate that the humic substances had a low degree of condensation of aromatic components [29] and low residence time of humic materials and dominance of fulvic acids over humic acids [48].

Notably, the changes observed in the current study were obtained 13 years after the establishment of the silvopastoral systems. It is expected that, during the early stage of development (e.g., first three years), the fast growing trees removed part of the soil nutrient reserves and thus reduced their availability for crop roots [49]. However, once the canopy was very closed (4-5 years, depending on species and tree density), some trees acted as a self-nourishing system via litter production and decay. It is expected that, in natural ecosystems, the organic matter decomposition is synchronized with the plant nutrient uptake and growth and thus $\mathrm{N}$ and other plant nutrients would be used efficiently [50]. However, in agroecosystems, the release of nutrient (particularly $\mathrm{N}$ ) is not in synchrony with the plant nutrient needs [51-53].

The pastures with only grasses depleted soil nutrients and acidified the soil; the effect is most dramatic in soil $\mathrm{P}$ availability since this element is below the critical level $\left(<10 \mathrm{mg} \mathrm{kg}^{-1}\right)$, whereas other nutrients still had high availability. For this reason, to maintain adequate productivity, it is necessary to apply $\mathrm{N}$ and $\mathrm{P}$ fertilizers to grasslands. The amounts of nutrients via fertilizers to be applied in the pastures are much higher than those for silvopastoral systems (e.g., $\mathrm{N}$ : 50 versus $25 \mathrm{~kg} \mathrm{ha}^{-1} ; \mathrm{P}_{2} \mathrm{O}_{5}: 50$ versus $25 \mathrm{~kg} \mathrm{ha}^{-1}$, resp.) [54]. Undoubtedly, this can have an impact on production costs. On the other hand, the use of biofertilizers such as $\mathrm{N}_{2}$ fixing bacteria, mycorrhizal fungi and $\mathrm{P}$ solubilizing microorganisms in the silvopastoral system with legume trees may provide several benefits [ $53,55-58]$. In this regard it is relevant to mention that legume trees can also transfer fixed $\mathrm{N}_{2}$ to associated grass via common mycorrhizal networks as reported by several authors $[12,13,59]$, which account for other significant benefits of silvopastoral systems for soil functioning in the tropics $[35,60]$.

\section{Conclusions}

Over time, the traditional system of livestock production based on only grasses has low return of soil nutrients and, consequently, the soil has been acidified and nutrient depleted. In contrast, after 13 years, the silvopastoral systems contributed significantly to nutrient cycling via litter production and decomposition; as a result of that, these systems can maintain or increase soil reaction and soil quality parameters.

\section{Conflict of Interests}

The authors declare that there is no conflict of interests regarding the publication of this paper.

\section{Acknowledgments}

The authors are grateful to CORPOICA and the Colombian Ministry of Agriculture and Rural Development for the financial support provided to Judith Martínez during her doctoral studies at the Universidad Nacional de Colombia at Medellin.

\section{References}

[1] D. Lamb, P. D. Erskine, and J. A. Parrotta, "Restoration of degraded tropical forest landscapes," Science, vol. 310, no. 5754, pp. 1628-1632, 2005.

[2] M. Herrero, P. K. Thornton, A. M. Notenbaert et al., "Smart investments in sustainable food production: revisiting mixed crop-livestock systems," Science, vol. 327, no. 5967, pp. 822-825, 2010.

[3] C. A. McAlpine, A. Etter, P. M. Fearnside, L. Seabrook, and W. F. Laurance, "Increasing world consumption of beef as a driver of regional and global change: a call for policy action based on evidence from Queensland (Australia), Colombia and Brazil," Global Environmental Change, vol. 19, no. 1, pp. 21-33, 2009.

[4] Y. S. Cajas-Girón, M. Jones, and F. L. Sinclair, "Combining tree diversity and cattle on seasonally dry pastures in Colombia," in Proceedings of the 2nd Congress of Animal Science, BAS, Yucatan, Mexico, 2002.

[5] S. E. Obalum, M. M. Buri, J. C. Nwite et al., "Soil degradationinduced decline in productivity of Sub-Saharan African soils: the prospects of looking downwards the lowlands with the Sawah ecotechnology," Applied and Environmental Soil Science, vol. 2012, Article ID 673926, 10 pages, 2012.

[6] J. Martinez, Litter production and decomposition in multistrata silvopastoral system and their effects on soil bio-organic properties in the Sinu river valley [Ph.D. dissertation], Universidad Nacional de Colombia, Medellin, Colombia, 2013. 
[7] S. Mejia, S. Reza, P. Argel et al., "Alternativas de manejo de pasturas de Colosuana o kikuyina (Bothriochloa pertusa) en sistemas ganaderos del tropico bajo," Informe Final, Corporacion Colombiana de Investigacion AgropecuariaCORPOICA. Ministerio de Agricultura y Desarrollo Rural, Córdoba, Colombia, 2008.

[8] Y. S. Cajas-Giron and F. L. Sinclair, "Characterization of multistrata silvopastoral systems on seasonally dry pastures in the Caribbean Region of Colombia," Agroforestry Systems, vol. 53, no. 2, pp. 215-225, 2001.

[9] R. Lal, "Laws of sustainable soil management," in Sustainable Agriculture, E. Lichtfouse, M. Navarrete, P. Debaeke, S. Veronique, and C. Alberola, Eds., pp. 9-12, Springer, Amsterdam, The Netherlands, 2009.

[10] M. F. Restrepo, C. P. Florez, N. W. Osorio, and J. D. León, "Passive and active restoration strategies to activate soil biogeochemical nutrient cycles in a degraded tropical dry land," ISRN Soil Science, vol. 2013, Article ID 461984, 6 pages, 2013.

[11] E. Murgueitio, Z. Calle, F. Uribe, A. Calle, and B. Solorio, "Native trees and shrubs for the productive rehabilitation of tropical cattle ranching lands," Forest Ecology and Management, vol. 261, no. 10, pp. 1654-1663, 2011.

[12] J. Sierra and P. Nygren, "Transfer of N fixed by a legume tree to the associated grass in a tropical silvopastoral system," Soil Biology and Biochemistry, vol. 38, no. 7, pp. 1893-1903, 2006.

[13] M. E. Wedderburn and J. Carter, "Litter decomposition by four functional tree types for use in silvopastoral systems," Soil Biology and Biochemistry, vol. 31, no. 3, pp. 455-461, 1999.

[14] J. H. Mcadam, A. R. Sibbald, Z. Teklehaimanot, and W. R. Eason, "Developing silvopastoral systems and their effects on diversity of fauna," Agroforestry Systems, vol. 70, no. 1, pp. 81-89, 2007.

[15] U. Ilstedt, A. Malmer, E. Verbeeten, and D. Murdiyarso, "The effect of afforestation on water infiltration in the tropics: a systematic review and meta-analysis," Forest Ecology and Management, vol. 251, no. 1-2, pp. 45-51, 2007.

[16] M. Lemenih, M. Olsson, and E. Karltun, "Comparison of soil attributes under Cupressus lusitanica and Eucalyptus saligna established on abandoned farmlands with continuously cropped farmlands and natural forest in Ethiopia," Forest Ecology and Management, vol. 195, no. 1-2, pp. 57-67, 2004.

[17] E. Barros, A. Neves, E. Blanchart, E. C. M. Fernandes, E. Wandelli, and P. Lavelle, "Development of the soil macrofauna community under silvopastoral and agrosilvicultural systems in Amazonia," Pedobiologia, vol. 47, no. 3, pp. 273-280, 2003.

[18] G. Schroth and F. Sinclair, Trees Crops and Soil Fertility: Concepts and Research Methods, CABI, Wallingford, UK edition, 2003.

[19] P. Betancourt, J. Gonzalez, B. Figueroa, and F. Gonzalez, "Materia organica y caracterizacion de suelos en procesos de recuperacion con coberturas vegetativas en zonas templadas de México," Terra, vol. 17, no. 2, pp. 139-148, 1999.

[20] M. R. Mosquera-Losada, E. Fernández-Núñez, and A. RigueiroRodríguez, "Pasture, tree and soil evolution in silvopastoral systems of Atlantic Europe," Forest Ecology and Management, vol. 232, no. 1-3, pp. 135-145, 2006.

[21] M. P. Eichhorn, P. Paris, F. Herzog et al., "Silvoarable systems in Europe-past, present and future prospects," Agroforestry Systems, vol. 67, no. 1, pp. 29-50, 2006.

[22] H. R. Grau, N. I. Gasparri, and T. M. Aide, "Agriculture expansion and deforestation in seasonally dry forests of northwest Argentina," Environmental Conservation, vol. 32, no. 2, pp. 140-148, 2005.
[23] B. Berg, "Litter decomposition and organic matter turnover in northern forest soils," Forest Ecology and Management, vol. 133, no. 1-2, pp. 13-22, 2000.

[24] S. Jose, "Agroforestry for conserving and enhancing biodiversity," Agroforestry Systems, vol. 85, pp. 1-8, 2012.

[25] B. M. Kumar, "Litter dynamics in plantation and agroforestry systems of the tropics-a review of observations and methods," in Ecological Basis of Agroforestry, D. R. Batish, R. V. Kohli, S. Jose, and H. P. Singh, Eds., pp. 181-216, CRC Press, Boca Raton, Fla, USA, 2008.

[26] L. R. Holdridge, Life Zone Ecology, Tropical Science Center, San José, Costa Rica, 1967.

[27] A. Calle, "What makes an early adopter? Transforming landscapes One farmer at a time," Tropical Resources Bulletin, vol. 27, pp. 7-14, 2008.

[28] A. Calle, F. Montagnini, and A. F. Zuluaga, "Farmers' perceptions of silvopastoral system promotion in Quindio, Colombia," Bois et Forets des Tropiques, vol. 300, pp. 79-94, 2009.

[29] M. Kononova, Soil Organic Matter, Pergamon, Oxford, UK, 1966.

[30] R. L. Westerman, Soil Testing and Plant Analysis, Soil Science Society of America, Madison, Wis, USA, 1990.

[31] P. L. Mafongoya, E. Kuntashula, and G. Sileshi, "Managing soil fertility and nutrient cycles through fertilizer trees in Southern Africa," in Biological Approaches to Sustainable Soil Systems, N. Uphoff, Ed., pp. 273-289, CRC Press, Boca Raton, Fla, USA, 2006.

[32] E. M. Fernandes, E. Wandelli, R. Perin, and S. Garcia, "Restoring productivity to degraded pasture lands in the Amazon through agroforestry practices," in Biological Approaches to Sustainable Soil Systems, N. Uphoff, Ed., pp. 305-322, CRC Press, Boca Raton, Fla, USA, 2006.

[33] R. V. Kohli, H. P. Singh, D. R. Batish, and S. Jose, "Ecological interactions in agroforestry: an overview," in Ecological Basis of Agroforestry, D. R. Batish, R. V. Kohli, S. Jose, and H. P. Singh, Eds., pp. 3-14, CRC Press, Boca Raton, Fla, USA, 2008.

[34] S. Jose, "Managing native and non-native plants in agroforestry systems," Agroforestry Systems, vol. 83, no. 2, pp. 101-105, 2011.

[35] G. Schroth and U. Krauss, "Biological soil fertility management for tree-crop agroforestry," in Biological Approaches to Sustainable Soil Systems, N. Uphoff, Ed., pp. 291-303, CRC Press, Boca Raton, Fla, USA, 2006.

[36] S. Jose, S. C. Allen, and P. K. R. Nair, "Tree-crop interactions: lessons from temperate alley-cropping systems," in Ecological Basis of Agroforestry, D. R. Batish, R. V. Kohli, S. Jose, and H. P. Singh, Eds., pp. 15-36, CRC Press, Boca Raton, Fla, USA, 2008.

[37] A. E. Lugo, E. Cuevas, and M. J. Sanchez, "Nutrients and mass in litter and top soil of ten tropical tree plantations," Plant and Soil, vol. 125, no. 2, pp. 263-280, 1990.

[38] F. Montagnini, "Soil sustainability in agroforestry systems: experiences on impacts of trees on soil fertility from a humid tropical site," in Ecological Basis of Agroforestry, D. R. Batish, R. Kumar, S. Jose, and H. P. Singh, Eds., pp. 239-249, CRC Press, Boca Raton, Fla, USA, 2008.

[39] R. Kershnar and F. Montagnini, "Leaf litter decomposition, litterfall, and effects of leaf mulches from mixed and monospecific plantations in Costa Rica," Journal of Sustainable Forestry, vol. 7, no. 3-4, pp. 95-118, 1998.

[40] J. Velasco, J. Camargo, H. Andrade, and M. Ibrahim, Mejoramiento del suelo por Acacia mangium en un sistema silvopastoril con Brachiaria humidicola, CATIE-Turrialba, San José, Costa Rica, 1998. 
[41] J. D. Leon, J. Castellanos, M. Casamitjana, N. W. Osorio, and J. C. Loaiza, "Alluvial gold-mining degraded soils reclamation using Acacia mangium plantations: an evaluation from biogeochemistry," in Plantations Biodiversity, Carbon Sequestration and Restoration, R. Hai, Ed., pp. 155-176, Nova Science, New York, NY, USA, 2013.

[42] J. Castellanos-Barliza and J. D. Leon, "Litter decomposition and nutrient release in Acacia mangium plantations established on degraded soils of Colombia," Revista de Biología Tropical, vol. 59, no. 1, pp. 113-128, 2011.

[43] A. M. Rodrigues, U. Cecato, N. M. Fukumoto, S. Galbeiro, G. T. Dos Santos, and L. M. Barbero, "Macronutrient concentrations and amounts in the animal excreta on mombaça grass pasture, fertilized with different phosphorus sources," Revista Brasileira de Zootecnia, vol. 37, no. 6, pp. 990-997, 2008.

[44] S. Van Ausdal, "Pasture, profit, and power: an environmental history of cattle ranching in Colombia, 1850-1950," Geoforum, vol. 40, no. 5, pp. 707-719, 2009.

[45] S. A. Barber, Soil Nutrient Bioavailability. A Mechanistic Approach, John Wiley \& Sons, New York, NY, USA, 1995.

[46] J. A. Parrotta, "Productivity, nutrient cycling, and succession in single- and mixed-species plantations of Casuarina equisetifolia, Eucalyptus robusta, and Leucaena leucocephala in Puerto Rico," Forest Ecology and Management, vol. 124, no. 1, pp. 45-77, 1999.

[47] D. Celentano, R. A. Zahawi, B. Finegan, R. Ostertag, R. J. Cole, and K. D. Holl, "Litterfall dynamics under different tropical forest restoration strategies in Costa Rica," Biotropica, vol. 43, no. 3, pp. 279-287, 2011.

[48] F. J. Stevenson, Humus Chemistry. Genesis, Composition, Reactions, John Wiley \& Sons, New York, NY, USA, 2nd edition, 1994.

[49] B. M. Kumar, S. Jacob George, V. Jamaludheen, and T. K. Suresh, "Comparison of biomass production, tree allometry and nutrient use efficiency of multipurpose trees grown in woodlot and silvopastoral experiments in Kerala, India," Forest Ecology and Management, vol. 112, no. 1-2, pp. 145-163, 1998.

[50] E. G. Gregorich and H. H. Janzen, "Microbially mediated processes: decomposition," in Handbook of Soil Science, M. Summer, Ed., pp. 106-119, CRC Press, Boca Raton, Fla, USA, 1998.

[51] S. Sundaramoorthy, M. S. Kumar, and S. M. Singh, "Soil biology in traditional agroforestry systems of the Indian Desert," in Desert Plants, Biology and Biotechnology, K. G. Ramawat, Ed., pp. 92-113, New York, NY, USA, 2010.

[52] K. Kumar and K. M. Goh, "Crop residues and management practices: effects on soil quality, soil nitrogen dynamics, crop yield, and nitrogen recovery," Advances in Agronomy, vol. 68, pp. 197-319, 1999.

[53] J. Leigh, A. Hodge, and A. H. Fitter, "Arbuscular mycorrhizal fungi can transfer substantial amounts of nitrogen to their host plant from organic material," New Phytologist, vol. 181, no. 1, pp. 199-207, 2009.

[54] Instituto Colombiano Agropecuario (ICA), Fertilizacion en Diversos Cultivos, ICA, Bogota, Colombia, 1992.

[55] M. Dulormne, J. Sierra, P. Nygren, and P. Cruz, "Nitrogenfixation dynamics in a cut-and-carry silvopastoral system in the subhumid conditions of Guadeloupe, French Antilles," Agroforestry Systems, vol. 59, no. 2, pp. 121-129, 2003.

[56] N. W. Osorio, Soil Nutrient Management in the Tropics, Universidad Nacional de Colombia, Medellin, Colombia, 2013.
[57] N. W. Osorio and J. D. Leon, "Roles of arbuscular mycorrizal association in plant nutrition and growth of tropical forestry and agroforestry in degraded soil reclamation," in Plantations Biodiversity, Carbon Sequestration and Restoration, R. Hai, Ed., pp. 127-154, Nova Science, New York, NY, USA, 2013.

[58] N. W. Osorio and M. Habte, "Synergistic effect of a phosphatesolubilizing fungus and an arbuscular mycorrhizal fungus on leucaena seedlings in an Oxisol fertilized with rock phosphate," Botany, vol. 91, pp. 274-281, 2013.

[59] Y. J. Li, Z. L. Liu, X. Y. He, and C. J. Tian, "Nitrogen metabolism and translocation in arbuscular mycorrhizal symbiote and its ecological implications," Chinese Journal of Applied Ecology, vol. 24, pp. 861-868, 2013.

[60] S. Zingore, R. Chikowo, G. Nyamadzawo, P. Nyamugafata, and P. L. Mafongoya, "Developments in the research of the potential of agroforestry for sustaining soil fertility in Zimbawe," in Ecological Basis of Agroforestry, D. R. Batish, R. V. Kohli, S. Jose, and H. P. Singh, Eds., pp. 217-237, CRC Press, Boca Raton, Fla, USA, 2008. 

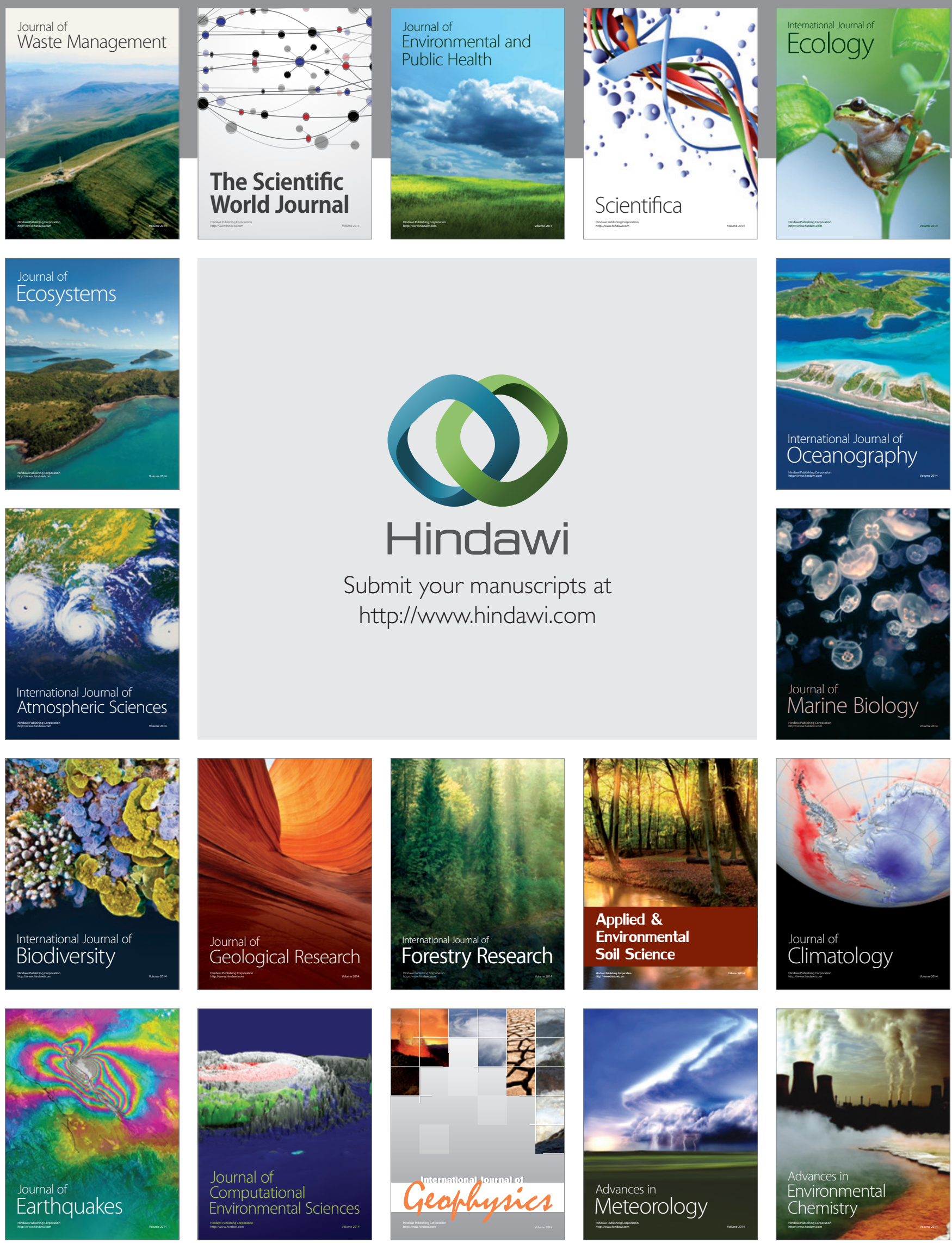